\title{
Formandens årsberetning 9. november 1990
}

Grundtvig-Selskabets årsmøde afholdtes 14. november $1989 \mathrm{i}$ Århus i Domkirkens lokaler i Sct. Clemens Gård. Ved den lejlighed talte kandidatstipendiat cand.theol. Kim Arne Pedersen om Grundtvigs natursyn (senere trykt i Grundtvig-Studier). På valg til styrelsen var Hellmut Toftdahl, der genvalgtes. Hvad organisatoriske forhold iøvrigt angår, skal nævnes, at redaktionen af Grundtvig-Studier (Gustav Albeck og William Michelsen) er blevet udvidet med Hellmut Toftdahl og Jens Holger Schjørring. Kassereren, sognepræst Lars Toftdahl, er udnæunt til præst i Canada under Dansk Kirke i Udlandet og i hans sted er udpeget sognepræst E. Jakob Petersen, Gelsted.

Selskabet havde med støtte fra N.F.S. Grundtvigs Fond planlagt et årsmøde på Vrå Højskole i september 1990 som et fællesmøde for den norske og danske afdeling; det måtte desværre aflyses på grund af manglende tilslutning.

Samarbejdet med Center for Grundtvig-studier ved Aarhus Universitet har fungeret særdeles tilfredsstillende. Det fremgår af den dobbeltårgang af Grundtvig-Studier (1989-90), der er udkommet for kort tid siden. Det rummer bl.a. en række af de foredrag, der blev holdt ved centerets møde på Sandbjerg Slot i september 1989 med bl.a. engelske og tyske deltagere og er et smukt vidnesbyrd om den voksende internationale interesse for Grundtvig, og de mange unge deltagere lover godt for Grundtvig-studiets fremtid. Centeret har videreført sit arbejde med en åben konference på Aarhus Universitet i september 1990 om poesi og teologi med Grundtvig som udgangspunkt, og i nært samarbejde med det teologiske fakultet i Durham planlægges en konference i Durham i april 1991 i forbindelse med projektet Grundtvig og England.

Hvad angår det internationale arbejde iøvrigt skal også nævnes, at Arthur Macdonald Allchin, der også er repræsenteret i Grundtvig-Studier 1989-90, i efterårssemestret 1990 som en af de første forskere på Center for Grundtvig-studier arbejder med det primære kildemateriale med henblik på at lave en bog på engelsk om Grundtvig, som vi kan vente os meget af. En gruppe af selskabets medlemmer med professor Theodor Jørgensen som utrættelig leder arbejder med en tysk Grundtvig-udgave, der nærmer sig sin afslutning. I forlængelse af den velbes $\emptyset$ gte 
Grundtvig-konference i Köln i 1988 udsender professor Paul Röhrig om kort tid den omfattende kongresberetning, som højskoleforstander Hans Henningsen, Askov, og selskabets formand er medredaktører af; denne store bog vil blive en længe savnet introduktion til Grundtvig på tysk. Det skal endvidere nævnes, at Paul Röhrig arbejder på at oprette et fast »Grundtvig-Werkstatt « på det pædagogiske fakultet ved Köln Universitet som udgangspunkt for mindre konferencer om Grundtvig-emner.

Den norske afdeling af Grundtvig-Selskabet fortsætter sit energiske arbejde under ledelse af pastor Dag Løkke; der har været afholdt en række lokale sammenkomster, og kontakten mellem de norske medlemmer styrkes i kraft af et særligt medlemsblad.

På Grundtvig-Selskabets vegne takker jeg Statens humanistiske Forskningsråd, Konsul George Jorck og Hustru Emma Jorck's Fond og N.F.S. Grundtvigs Fond for støtte til udgivelse af Grundtvig-Studier og selskabets $\emptyset$ vrige virksomhed. 